\title{
Effects of Feeding Squid By-Products on Growth Performance and Carcass Characteristics of Hanwoo Cows
}

\author{
Sang Min Lee', Sun Sik Jang', Seok Dong Lee', Seong Koo Hong ${ }^{1}$, Sung Sill Lee ${ }^{2}$ and Jae Seok \\ Woo* ${ }^{1}$. \\ ${ }^{1}$ National Institute of Animal Science, RDA, Pyeongchang 232-950, Korea \\ ${ }^{2}$ Division of Applied Life Science, Graduate School Gyeangsang National Univerity, Jinju 660-701, Korea
}

Received September 18, 2011 /Revised November 18, 2011 /Accepted December 19, 2011

\begin{abstract}
This study was conducted to evaluate the effect of feeding squid by-products on the growth performance and carcass characteristics of Hanwoo cows. Sixteen Hanwoo cows, aged 7 years and weighing $484.1 \pm 63.6 \mathrm{~kg}$, were randomly allocated to 2 feeding groups (8 animals per group): control and treatment (fed squid by-products). Both groups were fed ad libitum for 150d. Average daily gain was significantly higher in the treatment group than in the control group $(p<0.05)$. During the experimental period, DMI and feed conversion ratios were significantly lower in the treatment group than in the control group $(p<0.05)$. The results of yield traits, back fat thickness, rib eye area, and yield index were similar between the two groups. Carcass weights were $363.4 \mathrm{~kg}$ and $353.1 \mathrm{~kg}$ for treatment and control, respectively, but these differences were not statistically significant. Quality traits such as meat color, fat color, texture, and maturity were also not significantly different between the two groups. However, marbling score and rate of appearance of high quality grade $\left(1^{++}, 1^{+}\right.$, and 1$)$ were higher in the treatment group than in the control group. These results suggest that feeding squid by-products may improve the growth performance and carcass characteristics of Hanwoo cows.
\end{abstract}

Key words : Hanwoo cows, squid by-products, growth performance, carcass characteristics

\section{서 론}

우리나라 축산산업은 원료사료의 대부분을 수입에 의존하 기 때문에 생산비 중 사료비가 $70 \%$ 이상을 차지하며, 농수축 산 부산물을 이용한 대체 사료개발과 생산비 절감을 위한 다 양한 연구가 수행되고 있다. 우리나라 주요 수산자원인 오징 어는 근육부분만을 식품으로 이용하고 20 30\%에 해당하는 부 산물은 폐기되고 있다. 하지만, 오징어 부산물 중 내장에는 지방, 비타민 B군, 무기질 및 타우린이 많이 함유되어 있다. 타우린은 지방의 흡수촉진, 콜레스테롤 및 중성지방 농도 저 하, 뇌 발달, 심장 보호 작용, 삼투압조절, 생리기능, 성장 발달, 간 기능 보호 및 산화성 독성제거 등의 효과가 있는 것으로 알려져 있다[25,26]. 또한 오징어의 간에는 조지방함량이 $30 \sim 0 \%$ 로 이 중 $\omega-3$ 계 지방산인 $\mathrm{EPA}$ 및 $\mathrm{DHA}$ 의 함량이 많다 고 보고 되고 있다[4,15,16,29].

사료 내 다량의 지방 첨가는 반추위 내 가수분해된 long chain fatty acids의 반추위 미생물(프로토조아, 셀룰로스분 해 박테리아, 메탄생성 박테리아 등)의 활성억제[12,19,23, 24,27]와 섬유소를 물리적으로 피복하여 미생물이 섬유소를 분해하지 못하게 하는 작용 $[6,9,28]$ 등 반추동물의 소화생리 에 부의 효과를 나타낸다고 알려져 있는 반면 적정 수준의

${ }^{*}$ Corresponding author

Tel : +82-33-330-0617, Fax : +82-33-330-0660

E-mail : jswoo631@korea.kr
지방첨가는 단위 중량 당 에너지 밀도가 높아 비육후기 및 고능력우의 고에너지 사료로 이용되어 왔고[21,23], 메탄 생 성의 저감을 통한 지질의 정미 에너지 이용성 개선, 체내 지 방 합성관련 대사경로에서 acetate 또는 glucose 대신 longchain fatty acids의 직접적인 이용[7,18] 및 소장으로 지방산 유입량 증가를 통해 비육우의 근내지방 증진에 도움을 준다 [10]고 하였다.

따라서 본 연구는 국내 쇠고기 생산의 $40 \%$ 이상을 차지하 는 저능력 한우 암소는 단기간(4 10개월)에 보다 효과적인 영 양소 공급과 생산비 절감을 위해 지방 및 무기물 함량이 우수 한 오징어부산물의 급여가 산육 및 육질에 미치는 영향을 알 아보기 위해 수행하였다.

\section{재료 및 방법}

\section{공시동물 및 시험기간}

본 연구는 평균나이 7 세인 한우암소 16 두(평균체중 $484.1 \pm 63.6 \mathrm{~kg}$ )를 공시하여, 농촌진흥청 국립축산과학원 한우 시험장에서 처리구별 8 두씩 군사하여 5 개월간 사양시험을 수 행하였다.

\author{
시험설계 \\ 시험구 배치는 배합사료와 볏짚만 급여한 대조구와 배합사
}


료 내 오징어부산물을 첨가한 처리구, 등 2처리 8 반복으로 완 전 임의배치하여 산육 및 도체특성을 조사하였다.

\section{시험사료 및 사양관리}

시험에 이용된 사료는 주문생산 된 배합사료(Table 1)와 볏 짚을 이용하였고 오징어부산물은 강원도 옥계면에 위치한 오 징어부산물 가공장에서 건조 분말제품을 구입하여 배합사료 와 오징어부산물을 $4: 1$ 의 비율로 혼합하여 이용하였고 일반성 분은 Table 2와 3에 나타내었다. 시험축은 콘크리트 재질 바닥 의 톱밥 우사에서 각 처리구 당 8 두씩 가로 $790 \mathrm{~cm}$, 세로 800 $\mathrm{cm}$ 우방에서 사양관리 하였다. 사료급여는 자유채식을 원칙 으로 하여 배합사료는 하루에 2회(08:00, 16:00) 균등분배하였 고, 볏짚은 부족하지 않도록 보충하였다. 물과 미네랄 블록은 항시 섭취할 수 있도록 하였다.

\section{조사항목 및 조사방법}

체중은 시험개시일 부터 종료 시까지 우사 내에 위치한 우 형기(CAS Korea, Newton HT-501A, 가로: $110 \mathrm{~cm}$, 세로: 250 $\mathrm{cm}$, 높이: $200 \mathrm{~cm}$ )를 이용하여 매월 오전 사료급여 전에 측정 하였다. 증체량은 개시체중에서 매월 측정된 값의 차로 구하 였고, 각 처리별 평균값을 시험일수로 나누어 일당증체량을 구하였다. 사료섭취량은 오전 사료 급여 전 잔량을 조사한 후 전날 급여량에서 뺀 값으로 환산하였다. 시험사료의 일반성분 함량은 각각의 샘플 $(2 \mathrm{~kg})$ 을 수집하여 $\mathrm{AOAC}$ [1] 방법에 준하 여 분석하였다. 지방산 분석은 Folch [11] 등의 방법에 의해 추출한 지질을 $\mathrm{AOAC}$ [1]의 방법에 의해 fatty acid methyl ester화 시킨 후 gas chromatography (Agilent 6890N, Agilent Technologies Co., USA)를 이용하여 분석하였으며, 각각의

Table 1. Formula of concentrate

\begin{tabular}{lc}
\hline Ingredients & Mixture $(\%)$ \\
\hline Corn meal & 75.0 \\
Wheat bran & 12.4 \\
Soybean peel & 12.5 \\
Lactic acid bacteria & 0.1 \\
\hline
\end{tabular}

Table 2. Chemical composition of squid by-products

\begin{tabular}{lc}
\hline Item & Concentrate \\
\hline Dry matter (\%) & 15.19 \\
Crude protein (\%) & 35.20 \\
Ether extract (\%) & 46.17 \\
Saturated fatty acid & 28.53 \\
Unsaturated fatty acid & \\
Mono & 30.83 \\
Poly & 40.64 \\
Crude ash (\%) & 3.19 \\
Crude fiber (\%) & 0.25 \\
\hline
\end{tabular}

Table 3. Chemical composition of feeds used this experiment (\%, DM basis)

\begin{tabular}{lccc}
\hline Item & Concentrate & MSC $^{1)}$ & Rice straw \\
\hline Dry matter (\%) & 86.5 & 84.67 & 91.43 \\
Crude protein (\%) & 13.0 & 11.41 & 4.39 \\
Ether extract (\%) & 2.1 & 3.90 & 2.36 \\
Crude ash (\%) & 5.1 & 3.89 & 13.07 \\
Crude fiber (\%) & 4.6 & 3.69 & 29.57 \\
\hline
\end{tabular}

${ }^{1)}$ MSC: Mixture of squid by-products and concentrate.

fatty acid methyl ester standard (Sigma-Aldrich Co, St. Louis, MO, USA)를 이용하여 분석하였으며, 각각의 fatty acid methyl ester standard (Sigma-Aldrich Co, St. Louis, MO, USA)의 retention time과 비교하여 지방산 함량을 정량하였 다. 도체조사는 사양시험이 종료된 공시축을 출하하여 도축한 후, $0^{\circ} \mathrm{C}$ 에서 18 24시간 동안 도체를 현수시킨 후 육량판정요 인(도체중, 등지방두께, 배최장근단면적)과 육질판정요인(근 내지방도, 육색, 지방색, 조직감, 성숙도)을 소 도체등급판정기 준에 의거하여 축산물등급판정사가 평가하였다.

\section{통계처리}

본 시험에서 얻어진 성적들은 SAS (Statistical Analysis System software, 1999)를 이용하여 분산분석 및 $t$-test로 처리 구간 유의성 $(p<0.05)$ 을 검증하였다.

\section{결과 및 고찰}

\section{체중, 일당증체량 및 사료섭취량}

한우 비육 암소의 사료섭취량 및 산육특성은 Table 4 와 같 고, 개시 시 평균체중은 $484 \mathrm{~kg}$ 으로 동일하였고, 종료 시 체중 은 대조구 및 처리구가 각각 611.3 및 $629.0 \mathrm{~kg}$ 으로 오징어부산 물 첨가구가 높은 경향을 나타내었지만, 유의적 차이는 없었 다. 일당증체량은 처리구가 $1.07 \mathrm{~kg}$ 으로 대조구 $0.94 \mathrm{~kg}$ 보다 유의적으로 높았다 $(p<0.05)$. 사료섭취량에 있어서 대조구의 농후사료 섭취량이 처리구의 오징어부산물 첨가구 보다 높은 경향을 나타내었고, 볏짚 섭취량은 처리구가 조금 많았지만, 유의적 차이는 없었다. 건물섭취량에 있어 농후사료 섭취량이 높은 대조구가 처리구보다 유의적으로 높게 나타났다 $(p<0.05)$. 사료요구율은 처리구가 대조구보다 유의적으로 낮 은 결과(12.7 vs 9.74)를 나타내었다( $p<0.05)$. 본 연구에서 오징 어부산물의 처리가 대조구 보다 일당증체량이 높았다. Knott 등[17]에 의하면 양에서 지방급여가 일당증체량을 향상시켰다 고 하였다. 본 연구에서 일당증체량이 증가한 것은 오징어부 산물에 함유되어 있는 지방성분이 그 원인 중 하나일 것으로 보인다. 건물섭취량은 처리구가 대조구보다 낮았다. 반추위 이후 소화기관에 흡수되는 불포화지방산의 양이 증가할 경우 섭취량이 감소한다는 보고가 있다[3,22]. 따라서 본 연구에서 
Table 4. Effects of squid by-products on weight gain, average daily gain and feed intake of Hanwoo cows

\begin{tabular}{|c|c|c|}
\hline Item & Control & Treatment \\
\hline Initial $\mathrm{BW}^{1)}$ & $484.3 \pm 28.4$ & $484.0 \pm 16.5$ \\
\hline Final BW & $611.3 \pm 27.9$ & $629.0 \pm 17.8$ \\
\hline $\mathrm{ADG}^{2)}$ & $0.94 \pm 0.03^{b}$ & $1.07 \pm 0.06^{\mathrm{a}}$ \\
\hline \multicolumn{3}{|l|}{ Feed intake $(\mathrm{kg})$} \\
\hline Concentreate & $11.6 \pm 0.19$ & - \\
\hline MSC $^{3)}$ & - & $9.8 \pm 0.13$ \\
\hline Rice straw & $2.0 \pm 0.07$ & $2.1 \pm 0.05$ \\
\hline $\mathrm{DMI}^{4)}(\mathrm{kg})$ & $11.9 \pm 0.2^{\mathrm{a}}$ & $10.3 \pm 0.11^{b}$ \\
\hline Feed conversion ratio $(\mathrm{kg})$ & $12.7 \pm 0.33^{\mathrm{a}}$ & $9.74 \pm 0.51^{\mathrm{b}}$ \\
\hline
\end{tabular}

Means \pm standard error of mean.

${ }^{a, b}$ Means with different superscripts in the same row differ significantly $(p<0.05)$.

${ }^{1)} \mathrm{BW}$ : body weight.

${ }^{2)} \mathrm{ADG}$ : average daily gain.

${ }^{3)}$ MSC: Mixture of squid by-production and concentrate

${ }^{4)}$ DMI: dry matter intake.

섭취량이 감소한 것은 오징어부산물에 다량 함유된 불포화지 방산의 영향으로 생각된다. 반면 비육후기 거세우에 식물성 Oil의 급여시 건물섭취량에 영향을 주지 않으며[8], 보호지방 $2 \sim 6 \%$ 의 첨가도 영향이 없다[30]는 보고와는 일치하지 않는다. 그러나 이것은 암소와 거세우와의 차이일 수도 있으며, 식물 성 기름과 동물성 기름의 차이일 가능성이 있다. 또한 오징어 부산물 자체가 기호성을 저해할 가능성도 있다. 사료섭취량에 있어 대조구가 높았지만, 일당증체량 및 사료요구율에서 처리 구가 향상된 결과를 나타내었다. 이러한 결과는 대조구에 비 해 처리구의 사료 내 지방함량이 높아 고에너지의 결과로 판 단된다. 이전의 연구에서 Bock 등[5]은 비육후기 사료 내 지방 및 $\mathrm{Ca}$ 의 첨가수준에 따라 일당증체량이 증가하였다고 보고하 였고, Huffman 등[14]도 박편 옥수수에 $4 \%$ tallow를 첨가 시 일당증체량과 사료이용 효율이 증가하였다고 하였다. 따라서 오징어부산물의 급여는 한우 암소 비육 시 산육에 있어 긍정 적인 결과를 나타내었다.

\section{도체특성}

한우 암소 비육우의 오징어 부산물을 첨가한 혼합사료의 도체특성을 알아보기 위해 각 처리구별 8 두씩 공시한 시험축 의 도체성적은 Table 5와 같다. 각 처리구별 육량특성에 있어 서, 도체중은 각각 353.1 및 $363.4 \mathrm{~kg}$ 으로 처리구에서 높은 경 향을 나타내었고, 등지방두께 및 등심단면적에 있어서도 각각 13.4 및 $13.9 \mathrm{~mm}, 80.5$ 및 $81.8 \mathrm{~cm}^{2}$ 로 처리구에서 높은 경향을 나타내었다. 육량지수는 66.8 및 66.7로 비슷한 결과를 보였다. 육량등급 출현율은 $\mathrm{A}$ 등급 출현율이 처리구가 $62 \%$ 로 대조구 $(37 \%)$ 보다 높은 경향을 나타내었고, C등급 출현율은 $13 \%$ 로 같았다. 육질특성에 있어서 육색, 지방색 및 성숙도에 있어서
Table 5. Effects of squid by-products on carcass characteristics of Hanwoo cows

\begin{tabular}{lcc}
\hline Item & Control & Treatment \\
\hline Yield traits & & \\
Carcass weight $(\mathrm{kg})$ & $353.1 \pm 19.2$ & $363.4 \pm 11.7$ \\
Back fat thickness $(\mathrm{mm})$ & $13.4 \pm 2.8$ & $13.9 \pm 2.7$ \\
Rib eye area $\left(\mathrm{cm}^{2}\right)$ & $80.5 \pm 3.4$ & $81.8 \pm 1.8$ \\
Yield index & $66.8 \pm 1.3$ & $66.7 \pm 1.1$ \\
Yield grade (A:B:C, \%) & $37: 50: 13$ & $62: 25: 13$ \\
Quality traits & & \\
Marbling score & $3.8 \pm 0.5^{\mathrm{b}}$ & $5.4 \pm 0.5^{\mathrm{a}}$ \\
Meat color & $5.1 \pm 0.1$ & $5.0 \pm 0.0$ \\
Fat color & $3.5 \pm 0.2$ & $3.6 \pm 0.2$ \\
Texture & $4.6 \pm 0.4$ & $4.0 \pm 0.3$ \\
Maturity & $6.0 \pm 0.4$ & $6.1 \pm 0.4$ \\
Quality grade $\left(1^{++}: 1^{+}: 1: 2: 3, \%\right)$ & $0: 13: 37: 50: 0$ & $13: 22: 50: 0: 0$ \\
\hline
\end{tabular}

Means \pm standard error of mean.

$a, b$ Means with different superscripts in the same row differ significantly $(p<0.05)$.

각각 5.1, 5.0, 3.5, 3.6 및 6.0, 6.1로 유사한 결과를 나타내었고, 조직감은 4.6 및 4.0 으로 대조구에서 높은 경향을 나타내었다. 근내지방도는 처리구가 5.4로 대조구 3.8 보다 유의적으로 높 았고 $(p<0.05)$, 육질등급 출현율에서는 근내지방도의 결과에서 보는 바와 같이 처리구에서 1 등급 이상 출현율이 $100 \%$ 로 나타 났고, 대조구는 $50 \%$ 로 낮은 경향을 나타내었다. 식물성 지방 을 급여한 양에서 육질특성 및 근내지방도에 영향을 주지 않 았다는 이전의 연구결과[2,13,20]와 본 연구는 상반된 결과를 보였지만 또 다른 연구에서는 사료 내 높은 지방함량은 메탄 생성의 저감을 통한 지질의 정미 에너지 이용성 개선, 체내 지방 합성관련 대사경로에서 acetate 또는 glucose 대신 long-chain fatty acids의 직접적인 이용 $[7,18]$ 및 소장으로의 지방산 유입량 증가[10]를 통해 비육우의 근내지방을 향상 시 킨다고 하였고, 본 연구 결과에서도 지방함량이 높은 오징어 부산물의 급여가 한우암소의 근내지방을 향상시킨 것으로 판 단된다.

\section{References}

1. A.O.A.C. 1995. Official method of analysis. 16th eds. Association of Official Analytical Chemists. Washington, DC. USA.

2. Beaulieu, A. D., J. K. Drackley, and N. R. Merchen. 2002. Concentrations of conjugated linoleic acid (cis-9, trans-11-octadecadienoic acid) are not increased in tissue lipids of cattle fed a high-concentrate diet supplemented with soybean oil. J. Anim Sci. 80, 847-861.

3. Bremmer, D. F., L. D. Ruppert, J. H. Clark, and J. K. Drackley. 1998. Effects of chain length and unsaturation of fatty acid mixtures infused into the abomasum of lactating 
dairy cows. J. Dairy Sci. 81, 176-188.

4. Brestow, J. L. 2006. n-3 Fatty acids and cardiovascular disease. Am J. Clin. Nutr. 83, 1477-1482.

5. Bock, B. J., D. L. Hamon, Jr. R. T. Brandt, and J. E. Scheider. 1991. Fat source and calcium level effects on finishing steer performance, digestion, and metabolism. J. Anim Sci. 69, 2211-2224.

6. Davison, R. K. and W. Woods. 1960. Influence of fatty acids upon digestibility of ration components by lambs and upon cellulose digestion in vitro. J. Anim Sci. 19, 54-60.

7. Doreau, M. and Y. Chilliard. 1997. Digestion and metabolism of dietary fat in farm animals. Br. J. Nutr. 78, 15-35.

8. Eibs, M. S., B. J. Johnson, D. M. Wulf, B. D. Rops, and F. N. Owens. 2000. Effects of high-oil corn on feedlot performance, carcass characteristics and meat quality. Page 76 in Proc. Plains Nutr. Counc. Spring Conf. Texas A\&M Research and Education Center, Amarillo.

9. El-Hag, G. A. and T. B. Miller. 1972. Evaluation of whisty distillery by-products. J. Sci. Food Agric. 23, 247-258.

10. Fearon, A. M., C. T. Charlton, and D. J. Kilpatrick. 1994. A further investigation of the influence of dietary protected lipid supplements on the characteristics of cows' milk fat. J. Sci. Food Agric. 66, 247-256.

11. Folch, J., M. Lees, and G. H. S. Stanley. 1957. A simple method for the isolation and purification of total lipid from animal tissues. J. Biol. Chem 226, 497-509.

12. Galbraith, H. and T. B. Miller. 1973. The effect of metal cation and $\mathrm{pH}$ on the antibacterial activity and uptake of long-chain fatty acids. J. Appl. Bacteriol. 36, 635-646.

13. Gibb, D. J., F. N. Owens, P. S. Mir, Z. Mir, M. Ivan, and T. A. McAllister. 2004. Value of sunflower seed in finishing diets of feedlot cattle. J. Anim Sci. 82, 2679-2692.

14. Huffman, R. P., R. A. Stock, M. H. Sindt, and D. H. Shain. 1992. Effect of fat type and forage level on performance of finishing cattle. J. Anim Sci. 70, 3889-3898.

15. Johnson, E. J. and E. J. Scahaefer. 2006. Potential role of dietary $\mathrm{n} 3$ fatty acids in the prevention of dementia and macular degeneration. Am J. Clin. Nutr. 83, 1494-1498.

16. Kinsella, J. E. 1988. Food lipid and fatty acids importance in food quality, nutrition and health. Food Technol. 42, 124-145.

17. Knott, R. W., P. G. Hatfield, J. W. Bergman, C. R. Flynn, H. Van Wagoner, and J. A. Boles. 2003. Feedlot performance, carcass composition, and muscle and fat CLA concentrations of lambs fed diets supplemented with safflower seeds. Small Rumin. Res. 49, 11-17.

18. Machmüller, A., D. A. Ossowski, and M. Kreuzer. 2000. Comparative evaluation of the effects of coconut oil, oilseeds and crystalline fat on methane release, digestion and energy balance in lambs. Anim Feed Sci. Technol. 85, 41-60.

19. Maczulak, A. E., B. A. Dehority, and D. L. Palmquist. 1981. Effect of long-chain fatty acids on growth of rumen bacteria. Appl. Environ. Microbiol. 42, 856-862.

20. Madron, M. S., D. G. Peterson, D. A. Dwyer, B. A. Corl, L. H. Baumgard, D. H. Beermann, and D. E. Bauman. 2002. Effect of extruded full-fat soybeans on conjugated linoleic acid content of intramuscular, intermuscular, and subcutaneous fat in beef steers. J. Anim Sci. 80, 1135-1143.

21. Maeng, W. J. 1987. Important of fat and undegradable protein. Korean J. Anim Nutr. Feed 11, 1-17.

22. Oldick, B. S., C. R. Staples, W. W. Thatcher, and P. Gyawu. 1997. Abomasal infusion of glucose and fat-effect on digestion, production, and ovarian and uterine functions of cows. J. Dairy Sci. 80, 1315-1328.

23. Palmquist, D. L. and T. C. Jenkins. 1980. Fat in lactation rations: review. J. Dairy Sci. 63, 1-14.

24. Palmquist, D. L., T. C. Jenkins, and A. E. Jr. Joyner. 1986. Effect of dietary fat and calcium source on insoluble soap formation in the rumen. J. Dairy Sci. 69, 1020-1025.

25. Park, T. S., J. E. Park, J. S. Chang, M. W. Son, and K. H. Shon. 1998. Taurine content in Korean foods of plant origin. J. Korean Soc. Food Sci. Nutr. 27, 801-807.

26. Seo, J. H., Y. J. Jeong, G. D. Lee, and M. H. Lee. 1999. Moniteoring characteristics of protease isolated from aquid viscera. J. East Asian Soc. Dietary Life 9, 195-199.

27. Towne, G., T. G. Nagaraja, Jr. R. T. Brandt, and K. E. Kemp. 1990. Ruminal ciliated protozoa in cattle fed finishing diets with or without supplemental fat. J. Anim Sci. 68, 2150-2155.

28. Van der Horning, Y. and S. Tamminga. 1986. Effect of fat on rumen fermentation and future respective in research on rumen fermentation. A seminar in the EG program of condition of agricultural research. Rep. Eur. 10054 EN. publ. Commition Europ. Commum. Forsofsalaeg Foulum. Denmark. pp, 55-68.

29. Yazawa, K. and H. Kageyama. 1991. Physiology activity of docosahexaenoic acid. J. Japan Oil Chem Soc. 40, 974-978.

30. Zinn, R. A., S. K. Gulati, A. Plascencia, and J. Salinas. 2000. Influence of ruminal biohydrogentation on the feeding value of fat in finishing diets for feedlot cattle. J. Anim Sci. $78,1738-1746$ 


\section{초록 : 오징어 부산물의 급여가 한우암소 산육 및 도체특성에 미치는 영향}

이상민 ${ }^{1} \cdot$ 장선식 ${ }^{1} \cdot$ 이석동 ${ }^{1} \cdot$ 홍성구 $^{1} \cdot$ 이성실 ${ }^{2} \cdot$ 우제석 $^{1}{ }^{*}$

('농촌진흥청 국립축산과학원, ${ }^{2}$ 경상대학교 응용생명과학부)

본 연구는 한우 암소의 산육 및 도체특성에 있어 오징어 부산물의 급여 효과를 알아보기 위해 수행되었다. 한 우 16 두(나이 7세, 체중 $484.1 \pm 63.6 \mathrm{~kg}$ )를 대조구 및 처리구(오징어 부산물 첨가), 등 2그룹(각각 8두)으로 완전임의 배치하였다. 사료급여는 두 그룹 모두 자유채식토록 하여 150 일간 시험을 수행하였다. 일당증체량은 처리구가 대조구 보다 유의적으로 높았다( $<\times 0.05)$. 시험기간 내 사료섭취량 및 사료요구율은 처리구가 대조구 보다 유의적 으로 낮았다( $p \ll 0.05)$. 육량특성에 있어서, 등지방두께, 등심단면적 및 육량지수는 두 처리구간 비슷한 경향을 나타 내었고, 도체중은 처리구가 $363.4 \mathrm{~kg}$ 대조구 $353.1 \mathrm{~kg}$ 으로 처리구간 유의적 차이는 없었다. 육질특성에서는 육색, 지방색, 조직감 및 성숙도는 두 그륩간 유의적 차이가 없었다. 그러나 근내지방도 및 육질 1 등급 이상 출현율은 대조구 보다 처리구가 높았다. 그러므로 본 연구의 결과 오징어부산물의 급여는 한우 암소의 산육 및 도체특성을 향상시키는 것으로 생각된다. 